SHS Web of Conferences 12, 01022 (2014)

DOI: $10.1051 /$ shsconf/ 20141201022

C) Owned by the authors, published by EDP Sciences, 2014

\title{
A Competitive Model of Lenggong Valley as a Rural Heritage Destination in Malaysia
}

\author{
Nur Izwani Abdul Aziz ${ }^{1}$, Mastura Jaafar ${ }^{2}$, Fatimah Hassan ${ }^{3}$, Alaa J. Kadi ${ }^{4}$ \\ ${ }^{1,2,4}$ School of Housing, Building and Planning, Universiti Sains Malaysia, 11800, Penang, Malaysia \\ ${ }^{3}$ School of Distance Education, Universiti Sains Malaysia, 11800, Penang, Malaysia
}

\begin{abstract}
Besides rural attraction, Lenggong Valley has been acknowledged as an important archeological attraction in the state of Perak. On 30th June 2012, Lenggong Valley has been declared as the world heritage site by UNESCO for its archaeological heritage which includes four excavation sites divided into two clusters. Cluster 1 consists of the Bukit Bunuh-Kota Tampan core zone and its own buffer zone, while Cluster 2 consists of three core zones, namely Bukit Kepala Gajah, Bukit Gua Harimau and Bukit Jawa, all enclosed within a single buffer zone. For Perak, this recognition is important to attract more visitors to Perak this year, in conjunction with the Visit Perak Year 2012. From a tourism perspective, a place competitiveness can be increased by utilizing the unique resources of a particular place. The aim of this paper is to propose the competitiveness model of the Lenggong Valley. Various models on destination competitiveness will be reviewed.
\end{abstract}

\section{Introduction}

In recent years, tourism has become a highly competitive market. For this reason it is important that destinations are able to measure their competitiveness in order to identify their strengths and weaknesses and thereby develop their future strategies [1]. Evaluation of the competitiveness of tourism destinations is increasingly being recognised as an important tool in the strategic positioning and marketing analysis of destinations.

The literatures on competitiveness are wide-ranging, but there are still no clear definition or model discussing tourism destination competitiveness has yet been developed. There have been a number of variations explaining competitiveness, in terms of: a specific industry or group of industries, a country, a tourism destination, etc. Even within the same subject- for instance, a countrycompetitiveness can still be narrowed down to a specific topic : economical, social, political are just few examples to be mentioned [2].

The competitiveness of Lenggong Valley as a rural heritage destination has been insufficiently analyzed; there is no available result to be used so far for the design of an efficient economic tourism policy. Lenggong Valley tourism can be considered potentially stronger in archeology and nonarcheology resources than its value added products (e.g cultural, wellness, business etc.). In Malaysia, Lenggong Valley is one of the sites with great potential to be one of the main rural heritage attraction for tourism. 
It is located in Hulu Perak district, about $50 \mathrm{~km}$ north of Kuala Kangsar, the royal town of Perak. With 22,000 populations, the area covers approximately 113,000 hectare. "Perak Man", which is a human skeleton from the Paleolithic age, was discovered in the archaeological excavation site of Bukit Kepala Gajah in Lenggong Valley. Since then, there are other important findings from several sites within the area and because of that Lenggong Valley has become a lush archaeological territory in Malaysia.

On 30th June 2012, Lenggong Valley has been declared as the world heritage site by UNESCO, a specialized agency in United Nations (UN) that promote the exchange of culture, ideas, and information. In UNESCO's news release, Lenggong Valley was added to UNESCO's World Heritage List for its archaeological heritage which includes four excavation sites divided into two clusters. Cluster 1 consists of the Bukit Bunuh-Kota Tampan core zone and its own buffer zone, while Cluster 2 consists of three core zones, namely Bukit Kepala Gajah, Bukit Gua Harimau and Bukit Jawa, all enclosed within a single buffer zone. Figure 1 shows map of Lenggong Valley and Heritage Site of Lenggong Valley (Cluster 1 and Cluster 2). This study covered Cluster 1 and Cluster 2 as it is the area of heritage site only.

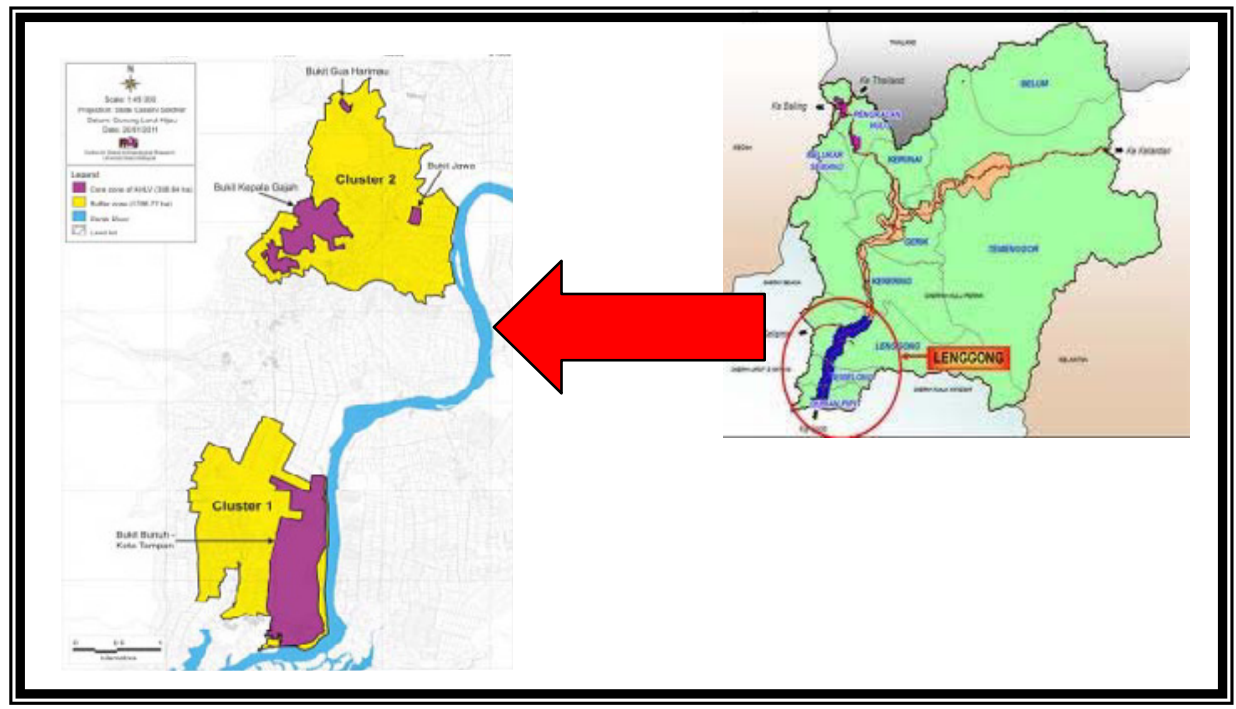

Figure 1. Heritage sites (cluster 1 and cluster 2) of Lenggong Valley.

Based on Munirah study, she classified attraction of Lenggong Valley into 2 categories, heritage and non-heritage [3]. Table 1 that showed Attraction for non-heritage based on Munirah's study.

Table 1. Non-heritage attraction of Lenggong Valley [3].

\begin{tabular}{|l|l|}
\hline Place Attributes & Potential Activities \\
\hline \multicolumn{2}{|c|}{ Non-heritage attraction } \\
\hline \multicolumn{2}{|c|}{ Activities of local community } \\
- local product such as fresh-water fish and & Culinary tourism \\
$\quad$ fish preserved & Food Product \\
- dodol & Agro festival \\
- $\quad$ serunding & \\
- $\quad$ klack pepper spices & \\
\hline
\end{tabular}




\section{Tourism destination competitiveness}

Various factors seem to have a relation to what 'being competitive' means for a destination. [4] suggests that destinations must put the environment first, make tourism a leader sector, strengthen the distribution channels in the market place and build a dynamic private sector. Authors concludes the factors that make a destination to be competitive considering variables that can be objectively measured such as number of arrivals, market share, tourist expenditure, etc or those more subjective and hard to quantify, such as 'cultural richness, 'quality of services', etc [4].

Authors who focuses on more objective measures of destination competitiveness (DC) defined it as ability 'to create and integrate value-added products that sustain its resources while maintaining market position relative to competitors' or 'to maintain its market position and share and/or improve upon them through time' [5-6]. This type of approach clearly supports the idea that competitiveness is directly related to high number of visitors and high generated tourism revenue for a destination.

However, another view of DC relates to economic prosperity of the residents of destination. This approach is sustained by the view that tourism growth often replaces industries that existed before it, thus damaging other economic activities of the destination [7] In this sense, although destinations can be competitive for attracting international visitors or investments, promoting the lifestyle of the place, generate peace and understanding, or for various other purposes [8] at the end, the economic prosperity of residents of a destination is a ultimate goal of destination.

From this perspective for a destination to be competitive is not an end but a means of increasing the standard of living of its residents. This study makes use of Ritchie and Crouch's definition which better translates the meaning of destination competitiveness into: 'the ability of a destination to increase tourism expenditure, to increasingly attract visitors while providing them with satisfying, memorable experiences and to do so in a profitable way, while enhancing the well-being of destination residents and preserving the natural capital of the destination for future generations' [9].

\subsection{Destination competitiveness model}

Despite various definitions of destination competitiveness, only few frameworks have been developed to evaluate the competitiveness of destinations [10]. Nevertheless, the topic has stimulated interest among scholars since increasing market competition makes it necessary for destinations to analyse their competitive position and to be aware of their strengths and weaknesses. There is a range of different destination competitiveness models $[4,8-9,11]$ and even more research regarding the analysis of particular destinations and their competitiveness [12-16].

The model developed by Ritchie and Crouch includes competitive and comparative advantages and the micro- and macro-environment. The model's core is built of five dimensions: (1) supporting factors and resources, of which the latent factors are infrastructure, accessibility, facilitating resources, hospitality, enterprises, and political will; (2) core resources and attractors, encompassing the constructs physiography and climate, culture and history, mix of activities, special events, entertainment, superstructure, and market ties; (3) destination management, composed of organisation, marketing, quality of service/experience, information/research, human resource management, finance and venture capital, visitor management, resource stewardship, and crisis management; (4) destination policy, planning and development, with latent factors of definition, philosophy/ values, vision, positioning/branding, development, competitive/collaborative analysis, monitoring and evaluation, and audit; (5) and finally, qualifying and amplifying determinants consisting of location, safety/security, cost/value, interdependencies, awareness/image, and carrying capacities (Crouch, 2011). These five dimensions include various indicators to measure both the customer perspective (demand) and the tourism industry perspective (supply) of a destination [9].

[8] also developed a general model of competitiveness to enable comparisons between countries and tourism sector industries. It is interesting to note that the [8] model stress out the elements of 'Resources' which provide the basis for destination competitiveness, referring to the various characteristics of a destination that make it attractive to visit and the foundations for 
successful tourism industry. The indicators were categorized into subgroups entitled endowed resources, created resources, supporting resources, destination management, situational conditions, demand factors and market performance indicators. Endowed resources include natural (lakes, mountains, beaches) and heritage (such as cuisine, language, traditions) resources. Created resources include tourism infrastructure, special events, the range of available activities, entertainment and shopping. Supporting resources refer to general infrastructure, quality of service, accessibility of destination, among other secondary resources that act as foundation for a successful tourism industry. The subgroup of Destination Management is the second core component of the model includes government (activities undertaken by public sector) and industry (activities undertaken by the private sector). Situational conditions refer to all the external forces (social, cultural, environmental) that influence the competitiveness of a destination, and its corresponds to the Qualifying and Amplifying determinants [8].

A further attempt to create a model of destination competitiveness has been put forward by Heath who claimed that existing models do not deal adequately and integrative with certain issues. Heath's model combines main elements of destination competitiveness proposed in the literature (e.g. infrastructure) as well as core indicators used by tourism researchers (e.g. authentic experiences, attractors) [11]

All the above mentioned models served as a foundation for the development of the so called Integrated model, which was used for this research. From a perspective of this study, Dwyer and Kim model was the most relevant to be adopted. It brings together the main elements of destination competitiveness, it provides the distinction between inherited and created resources seemed to be useful, and the category of destination management - which was the important issue of our research that shape and influence a destination is competitive strength.

\subsection{Destination management}

Destination Management includes factors that enhance the attractiveness of the inherited and created resources. The indicators were categorized into three main subgroups entitled destination marketing management, destination policy, planning and development and human resources development [8].

\subsubsection{Destination marketing management}

When implementing their marketing activities, destination management organisations can contribute to sustainable tourism through their actions depending on their focus; it is either promotional and facilitation strategy. The marketing activities of DMOs are mainly centred on the promotion of the destination as a whole. Hassan point out that to maintain tourism competitiveness, destination management should focus on a systematic examination of unique comparative advantages that provide a special long term appeal to the target travel customer segments. He claims that destinations are winning competitive battles by careful analysis and response to the core values and needs of the segmented marketplace' [5].

\subsubsection{Destination policy, planning and development}

According to [8], tourism must be developed and managed within a hierarchy of controls, ranging from the local to the territorial, to the national and eve to the international level. The responsibilities at each level must be clearly identified and a process of accountability must be implemented. Tourism planning requires an understanding of the meaning of sustainable development and the guiding values for promoting sustainable tourism. It requires that communities be made to be aware and understand of the tourism industry and its impacts as well as the various processes to integrate and engage in participatory planning. It is important to consider which sustainable development principles can be implemented through community control and which need to be implemented through controls at a higher level [8]. 


\subsubsection{Human resource development}

In tourism context, according to Beuno, 'since between competition between destinations is determined by skills, human resources are a central factor in achieving competitiveness because of the new opportunities brought about by new technologies and the importance of consumer loyalty in maintaining high demand' [17]. Workers in organisations that seek to be competitive must be highly skilled, reliable, educated individuals [18]. They must be able to understand and use the new forms of information technology and the information being made available, adapt to rapidly changing organisation forms, and work well with others. The links between knowledge creation and use and effective management of the firm's human resources need further examination. Training has an important role to play in the development of the three dimensions of organisational knowledge: depth of knowledge, competence, and exploratory/exploitative knowledge [19].

\section{Proposing framework on Lenggong Valley tourism destination competitiveness}

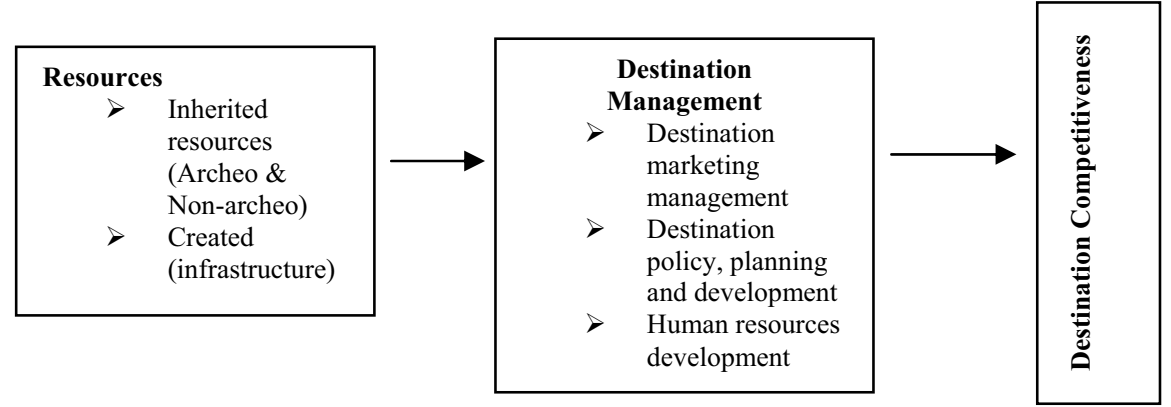

Figure 2. Lenggong Valley destination competitive framework.

\subsection{Resources}

The resources factor was identified as the most important dimension of Lenggong Valley tourism destination competitiveness. Tourism destinations are so much dependent on inherited resource as in context of Lenggong Valley resources it is divided into archaeology resources and non-archeology resources. Non-archeology can be classified as natural, culture/heritage and range of activities (local community activities. Table 1 showed archaeology and non-archeology resources which has the potential to be highlighted as Lenggong competitiveness.

Taken together, inherited resource and created resource provide various characteristics of a destination that make it attractive for tourist to visit. This is why these two factors are all placed in the same box. Tourism infrastructure (created resources) were also a key factors associated with tourism destination competitiveness. A study about Cambodia tourism industry stated that "Cambodia has a lot of endowed resources, but lacks of supporting resources and factors to achieve tourism competitiveness" [20]. Facilities play an important role in tourism competition. So, destination management organization must play their role to ensure all the facilities provided to tourist are well maintained. 
Table 2. List of archaeology and non-archeology resources of Lenggong Valley

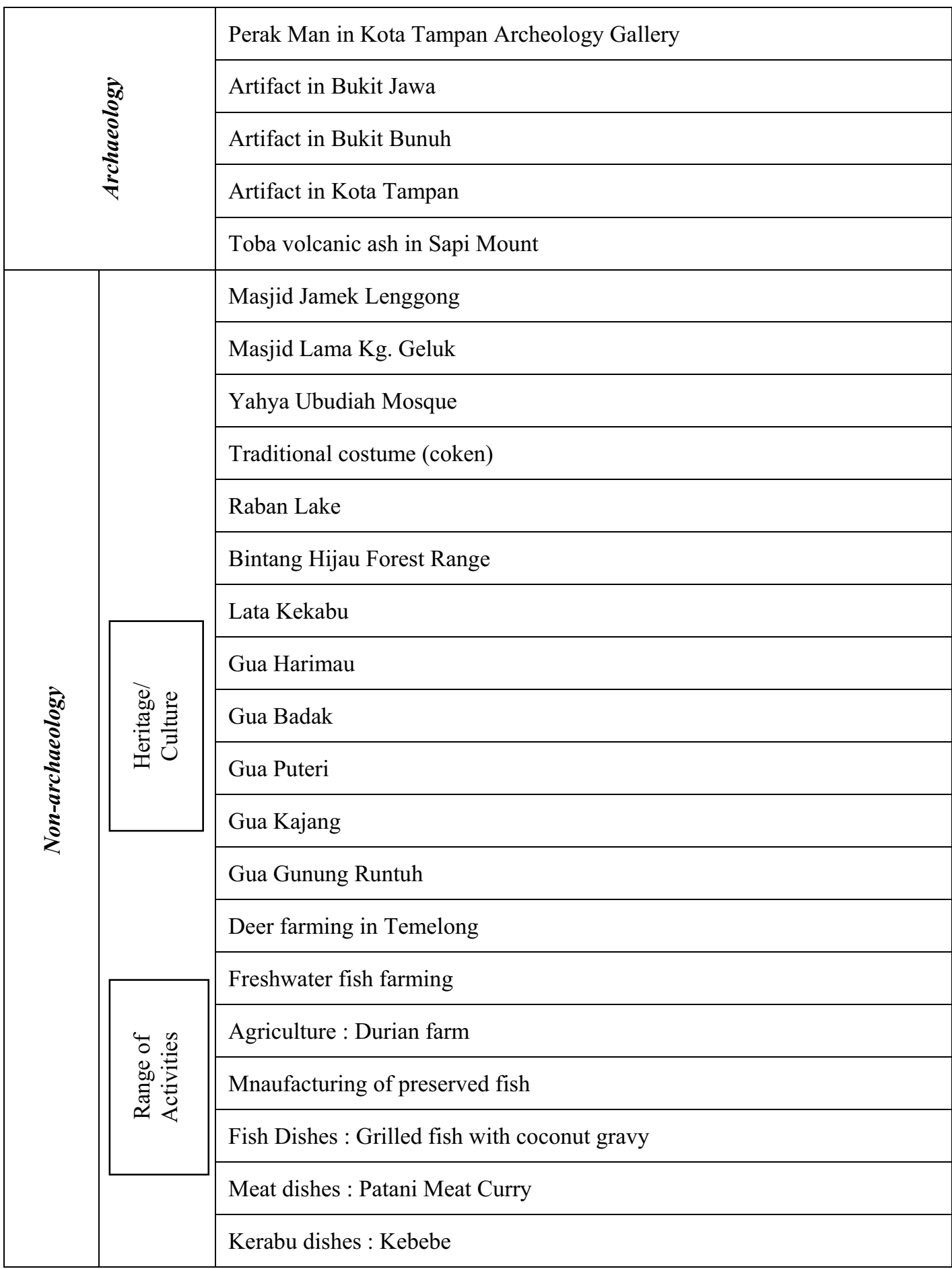




\subsection{Destination management in Lenggong Valley Heritage Site}

Since being recognized by UNESCO as one of the World Heritage Site in 2012, the Department of Heritage has been managing the heritage sites in Lenggong Valley and Lenggong Archeological Gallery. Their responsibilities are to protect and conserve archaeological sites in Lenggong Valley. If there is any development project or activity being planned in the zoned area, the Department of Heritage will take appropriate action. Prior to that, the Department of Heritage only conducted periodical monitoring on the sites.

Besides, Department of Heritage also played their role in conducting heritage awareness campaigns. As an example, after receiving recognition from UNESCO in 2012, 8 programs were organized by the villagers in the Valley Lenggong. Normally, the campaigns being organized at the museum were for the head of villages and members of the council (among community leaders); some of the campaigns were conducted in the mosques (cluster 1: mosque at $\mathrm{Kg}$. Banggol Batu, mosque at Kg Banggol Belimbing, cluster 2: mosque at Kg Gua Badak and Kg Masjid Lenggong).

These programs were also being organized for villagers in the public hall at Kg Luat and Kota Tampan. Among the activities to attract participants were exhibition, coloring competition for children, lucky draw and banquet. In order to invite inform people of the campaigns, invitations letters were distributed to the head of villagers. The aim of these campaigns is to raise awareness of local community on the importance of preserving the heritage sites in Lenggong.

\subsection{Lenggong Valley Competitiveness}

According to [2], quantitative performance of a destination can be measured by looking at numbers such as annual tourism receipts, level of expenditure per tourist and length of overnight stays [20]. There is no unique way to measure competiveness of different destinations. Researchers argue that no universal and optimal competitiveness model exists for every destination. But, in case of Lembah Lenggong, it is suitable to measured the competitiveness by advantages and uniqueness of archeological resources and natural resources, heritage as well as community activities, Lenggong Valley has the potential to become an attractive tourist destination. Thereby its place competitiveness can be increased.

In Figure 2, the category is divided into two types which is inherited and created resources. Inherited resources in turn can be classified as Archeology and Non-archeology, while created resources were infrastructure. In the model presented here, resources available in Lenggong Valley can be promoted further to enhance tourist attractions trough proper and efficient of Department of Heritage.

Destination Management factors are those that 'can enhance and appeal of the core resources and attractors, strengthen the quality and effectiveness of the supporting factors and resources [9]. The box representing Destination competitiveness is linked directly with Resources and Destination Management. Excellent combination of resource management and a destination management will enhance the competitiveness of Lenggong Valley.

\section{Discussion and Conclusion}

The role of the destination management based on framework is to understand how tourism destination competitiveness can be enhanced and sustained. Therefore, it is important for Lenggong Valley to realize its real competitive position and its competitive advantages and disadvantages.

Destination management should through sufficient management of archeology, non-archeology ad created resources, provide the basis for differentiation from competitive countries. Destinations have to face the challenge of managing and organizing their resources efficiently in order to supply a holiday experience that must outperform alternative destination experiences. 
Results of the research have practical implication on destination management and marketing and on entities that drive the destinations development. However, this research presents only one single step in the analysis of the competitiveness of Lenggong Valley as a rural heritage destination. More research needs to be done on the importance of different elements of destination competitiveness. Moreover, the model of destination competitiveness should be applied periodically and monitored by time to time. This can provide a moving picture of the destination competitiveness at different points in time.

\section{References}

1. P. Keller \& E. Smeral. Increased international competition: New challenges for tourism policies in European countries. In WTO/CEU ETC Joint Seminar (1997)

2. M. Kozak \& M. Rimmington. Measuring tourist destination competitiveness: conceptual considerations and empirical findings. International Journal of Hospitality Management, 18,3, 273-283 (1997)

3. Munirah, An analysis on characteristics and performance of tourism related SMEs in Lenggong Valley, Perak (2014)

4. A. Poon. Tourism, technology and competitive strategies. CAB international (1993)

5. S.S. Hassan. Determinants of market competitiveness in an environmentally sustainable tourism industry. Journal of travel research, 38,3, 239-245 (2000)

6. A.M. d'Hauteserre. Lessons in managed destination competitiveness: the case of Foxwoods Casino Resort. Tourism Management, 21, 1,23-32 (2000)

7. D. Buhalis. Marketing the competitive destination of the future. Tourism management, 21,1 , 97$116(2000)$

8. L. Dwyer, \& C. Kim. Destination competitiveness: determinants and indicators. Current issues in tourism, 6, 5,369-414 (2003)

9. J.B. Ritchie \& G.I. Crouch. The competitive destination: A sustainable tourism perspective. Cabi. (2003)

10. S. Hudson, B. Ritchie \& S. Timur. Measuring destination competitiveness: An empirical study of Canadian ski resorts. Tourism and Hospitality Planning \& Development, 1, 1, 79-94 (2004)

11. E. Heath. Towards a model to enhance destination competitiveness: A Southern African perspective (2003)

12. Z.U. Ahmed, \& F. Krohn. B.Reversing the United States' declining competitiveness in the marketing of international tourism: a perspective on future policy. Journal of Travel Research, 29, 2,23-29 (1990)

13. M. Kozak, S. Baloğlu, \& O. Bahar. Measuring destination competitiveness: Multiple destinations versus multiple nationalities. Journal of Hospitality Marketing \& Management, 19, 1, 56-71 (2009)

14. K.S. Chon, \& K.J.Mayer. Destination competitiveness models in tourism and their application to Las Vegas. Journal of Tourism Systems and Quality Management, 2, 3,(1995)

15. B. Faulkner, M. Oppermann \& E. Fredline. Destination competitiveness: An exploratory examination of South Australia's core attractions. Journal of Vacation Marketing, 5,2, 125-139 (1999)

16. J.A. Mazanec, K. Wöber \& A.H. Zins. Tourism destination competitiveness: from definition to explanation. Journal of Travel Research, 46, 1,86-95 (2007)

17. G.I.Crouch. Destination competitiveness: an analysis of determinant attributes. Journal of Travel Research (2010)

18. A. Bueno. Competitiveness in the tourist industry and the role of the Spanish public administration. Turizam 47 , 4, 316-31 (1999) 
19. J. Duffey. Competitiveness and human resources. California Management Review (Spring), $92-$ 100 (1988)

20. S. Narashimbha, Organisation knowledge, human resource management, and sustained competitive advantage: Toward a framework. Competitiveness Review, 123-35 (2000)

21. C.Y. Chens, P. Sok, \& K. Sok. Evaluating the competitiveness of the tourism industry in Cambodia: Self-assessment from professionals. Asia Pacific Journal of Tourism Research, 13, 1, 41-66 (2008) 